\title{
Ecostacking: maximising the benefits of ecosystem services
}

\author{
Heikki MT Hokkanen ${ }^{1}$
}

Published online: 16 October 2017

(c) Springer Science+Business Media B.V. 2017

Ecosystem service providers (ESP) are increasingly seen as critically important allies in securing the long-term sustainability of agriculture and food production. With public pressure to phase out agrochemicals that were once considered safe to the environment, we must increasingly rely on ecosystem services to maintain or to increase agricultural production, and to keep it ecologically, economically, and socially sustainable (Fig. 1).

Biodiversity at all levels from crop plant genetic variability, to soil microbial assemblages, to botanical composition in a field, and to diversity of the agroecosystem landscape, have all been shown to affect the delivery of ecosystem services to crops by the ESP. So far these positive effects have never been combined in a synergistic manner to optimise the level of ecosystem services obtainable in a given environment.

I propose making a full use of the benefits accruable from ecosystem services via stacking and conservation of functional biodiversity in our cropping systems-by "ecostacking". Stacking implies here combining in a synergistic manner the beneficial services of functional biodiversity from all levels and types. This is a comprehensive approach, where the various ecosystem service providers are fully integrated with the rest of the cropping system including agronomic practices. ESP involved include primarily beneficial arthropods such as predators and parasitoids for the control of pests, seed feeders and other specialist herbivores for weed control, and pollinating insects. Many other ESP also need to be involved, for example vertebrates (e.g.

Heikki MT Hokkanen

heikki.hokkanen@helsinki.fi

1 Department of Agricultural Sciences, University of Helsinki, Helsinki, Finland small mammals, bats, and birds as seed feeders and predators of pests), microbes, and the crop plants themselves (via induced resistance mechanisms). Microbes provide invaluable ecosystem services including pest, disease, and weed control, either directly as components of suppressive soils or as plant colonisers (as endophytes or as epiphytic microbial flora). Soils suppressive for plant pathogenic microbes have long been known (e.g. Hornby 1983, Schlatter et al. 2017), but awareness and potential of soils suppressive to insect pests have received only little attention (but see Hokkanen and Menzler-Hokkanen, 2017). Endo- and epiphytes and their role in steering arthropod-plant interactions are under intensive study, and utilisation of microbe-mediated bottom-up effects in crop protection is in its infancy (Shikano et al. 2017).

The scientific community needs to develop, design, and implement integrated systems for optimised provision of ecosystem services and use of plant protection tools, with focus on ecological, economic, and social sustainability of the integrated system. To facilitate full integration, there is a need to develop "bioinspired" plant protection products and tools, based on the use of natural products active against pests and pathogens, or that trigger plant defense responses. These products and tools are needed as successor technology to replace phased-out chemical pesticides.

Increased knowledge about arthropod-plant interactions and factors modulating them is necessary in order to develop and support sustainable crop production. Basic research is focusing on factors explaining the mechanisms involved in these interactions, identifying the key providers of functional biodiversity services, and quantifying the supply of ecosystem services such as biological control, pollination, and plant defense activators. A large amount of scientific literature already exists on individual components of functional biodiversity. The ideas, methods, and techniques focusing on 


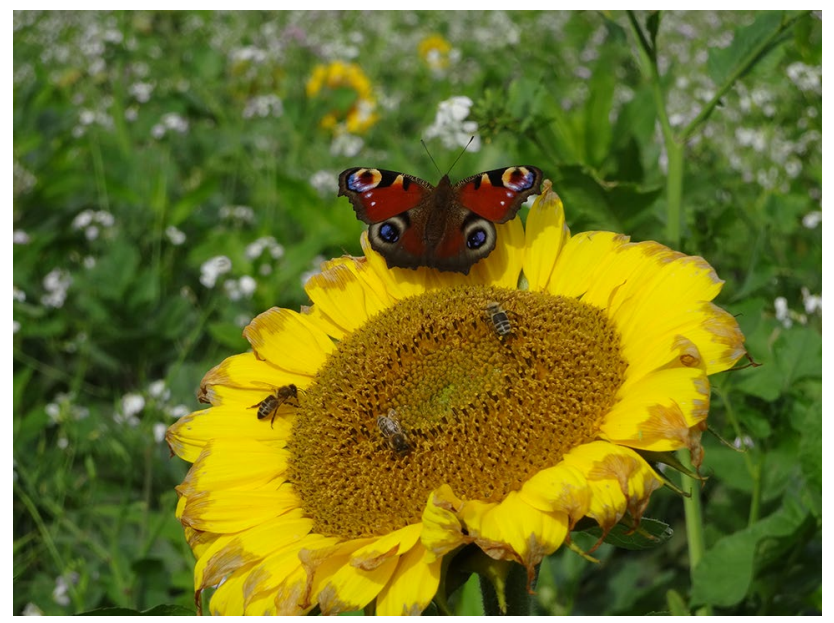

Fig. 1 Functional biodiversity in action on flower mixtures sown for biomass production in Bavaria, Germany

single components of the system have to be expanded and stacked, considering the pedo-climatic frame, the crop, the existing landscape elements, and the socio-economic conditions in the area, and combined in a meaningful and synergistic package approach. This is why we need to increase our knowledge on stacking of the most promising and productive ecosystem services into an operational, profitable, and sustainable whole.

The purpose of coining the term "ecostacking" is to give food for thought and inspiration for the direction of research. The journal Arthropod-Plant Interactions is a natural platform for publishing high-quality research papers on ecostacking and its component approaches and mechanisms, and we look forward to receiving manuscripts in this topic area.

\section{References}

Hokkanen HMT, Menzler-Hokkanen I (2017) Use of entomopathogenic fungi in the insect pest management of Brassica oilseed crops. In: Reddy GVP (ed) Integrated management of insect pests on canola and other Brassica oilseed crops. CAB International, Wallingford, pp 373-382

Hornby D (1983) Suppressive soils. Annu Rev Phytopathol 21:65-85. https://doi.org/10.1146/annurev.py.21.090183.000433

Schlatter D, Kinkel LL, Thomashow LS, Weller DM, Paulitz TC (2017) Disease suppressive soils: new insights from the soil microbiome. Phytopathol. https://doi.org/10.1094/PHYTO-03-17-0111-RVW

Shikano I, Rosa C, Tan C-W, Felton GW (2017) Tritrophic interactions: microbe-mediated plant effects on insect herbivores. Annu Rev Phytopathol 55:313-331. https://doi.org/10.1146/ annurev-phyto-080516-035319 